\title{
Urinary calcium to creatinine ratio to predict preeclampsia and use of calcium supplementation to prevent preeclampsia
}

\author{
Anjali M. Munge, Meena N. Satia*
}

Department of Obstetrics and Gynaecology, Seth G.S. Medical College \& K.E.M. hospital, Mumbai, Maharashtra, India

Received: 08 April 2016

Revised: 19 April 2016

Accepted: 22 April 2016

*Correspondence:

Dr. Meena N. Satia,

E-mail: meenasatia@kem.edu

Copyright: (C) the author(s), publisher and licensee Medip Academy. This is an open-access article distributed under the terms of the Creative Commons Attribution Non-Commercial License, which permits unrestricted non-commercial

\begin{abstract}
Background: Incidence of preeclampsia is around 5-10\% of all pregnancies, and in developing countries around 4$18 \%$. There is hypercalciuria during normal pregnancy, while pre-eclampsia is associated with hypocalciuria and low urinary calcium to creatinine ratio. Low calcium intake has been hypothesized to cause increase in blood pressure. The present study was carried out to investigate significance of urinary CCR in prediction of preeclampsia \& role of calcium supplementation in reducing preeclampsia.

Methods: 100 pregnant patients were divided into two groups, 50 cases and 50 controls. A spot urine sample was collected for estimation of CCR at around gestational age of 20-24 weeks. Cases were given 2 gm of calcium supplementation. Controls were $1 \mathrm{gm}$ calcium .Then at each visit both the groups, were evaluated for symptoms of preeclampsia. Urinary calcium to creatinine ratio was calculated and those with ratio <or $=0.04$ were considered test positive and those with ratio of $>0.04$ were considered test negative.

Results: The test (urinary CCR $<=0.04$ ) was positive in 16 patients, 9 developed preeclampsia. The test was negative test (urinary CCR >0.04) in 84 patients and in those only 5 developed pre eclampsia. Urinary CCR had sensitivity of $63.63 \%$, specificity of $94.87 \%$. Out of 50 cases, only 3 developed preeclampsia. Out of 50 controls, 11 developed preeclampsia.

Conclusions: Urinary CCR between 20-24wks of gestation will be an effective screening method for impending preeclampsia. Calcium supplementation (2gms/day) can help in prevention of preeclampsia.
\end{abstract}

Keywords: Preeclampsia, Urinary calcium to creatinine ratio (CCR), Calcium supplementation

\section{INTRODUCTION}

Around the world, an estimated 529,000 women die during pregnancy or childbirth. ${ }^{1}$ Incidence of preeclampsia is around $5-10 \%$ of all pregnancies, and in developing countries around $4-18 \% .^{2-4}$ It has been reported that, pre-eclampsia is a major cause of both maternal and fetal morbidity and mortality (Bringman et al., 2006).

Unfortunately, the pathophysiology of this multisystem disorder, characterized by abnormal vascular response to placentation, is still unclear.
Delivery is the only curative treatment for pre-eclampsia. Screening women at high risk and preventing recurrences are key issues in the management of pre-eclampsia.

There is hypercalciuria during normal pregnancy, while pre-eclampsia is associated with hypocalciuria and low urinary calcium to creatinine ratio. This phenomenon occurs early enough and persists throughout gestation, so it is useful for early identification of patients at risk.

The present study was carried out to investigate the significance of urinary calcium to creatinine ratio in prediction of preeclampsia and thus may identify 
population at greater risk to be included in primary prevention programme.

An inverse relationship between calcium intake and hypertensive disorders of pregnancy was first described in $1980 .^{5}$ This was based on the observation that Mayan Indians in Guatemala, who traditionally soak their corn in lime before cooking, had a high calcium intake and a low incidence of pre-eclampsia and eclampsia. A very low prevalence of pre-eclampsia had been reported from Ethiopia where the diet, among other features, contained high levels of calcium. ${ }^{6}$

These observations were supported by other epidemiological and clinical studies and led to the hypothesis that an increase in calcium intake during pregnancy might reduce the incidence of high blood pressure and pre-eclampsia among women with low dietary calcium.

\section{Aims of the study}

- To determine the predictive value of urinary calcium to creatinine ratio in a spot urine sample in asymptomatic pregnant female between 20-24 weeks of gestation, for preeclampsia.

- To determine the use of calcium supplementation (2 grams/day) in prevention of preeclampsia.

\section{METHODS}

Out of women attending A.N.C. O.P.D. in tertiary care hospital, pregnant women who met the inclusion and exclusion criteria were selected. The study was initiated after seeking approval from ethics committee (CARE). Patients were enrolled for study after obtaining written informed consent from patient and husband or one of the relative.

Our study was randomized, prospective, interventional, case-control study. Randomization was done by means of computer generated randomization list (SAS 9.1 software package).

Inclusion criteria were pregnant women around 20-24 weeks of gestation. Exclusion criteria were history of chronic hypertension ,diabetes, renal disease, urolithiasis, preeclampsia in previous pregnancy, family history of preeclampsia, patient who have proteinuria and those with a baseline blood pressure of more than or equal 140/90 $\mathrm{mmHg}$ at registration in A.N.C. O.P.D.

Then 100 normotensive patients were divided into two groups, 50 cases and 50 control by simple random method.Cases were $2 \mathrm{gm}$ of calcium supplementation in the form of tablet calcium lactate $500 \mathrm{mg}$ four times a day. Controls were $1 \mathrm{gm}$ calcium in the form of tablet calcium lactate $500 \mathrm{mg}$ twice daily which was routine ANC dose. This routine ANC dose will eliminate the bias due to low dietary calcium intake especially in developing country like ours.

A spot urine sample was collected for estimation of calcium and creatinine at around gestational age of 20-24 weeks of all patients. Urinary calcium was estimated by Ortho-Cresolphthalein Complexone (CPC) method, urinary creatinine was estimated by Jaffe's method.

Then at each visit both the groups, was evaluated by eliciting history for symptoms of preeclampsia and imminent eclampsia such as oedema, vomiting, epigastric pain, decreased urine output and visual disturbances. Blood pressure was measured and urine was tested for proteinuria.

According to the National High Blood Pressure Education Program Working Group (NHBPEP) and the American College of Obstetricians and Gynecologists (ACOG), hypertension in pregnancy is defined as diastolic blood pressure equal to or greater than 90 $\mathrm{mmHg}$ or systolic blood pressure level of $140 \mathrm{mmHg}$ or higher after 20 weeks of gestation in a woman with previously normal blood pressure, (NHBPEP,2000;ACOG,2002).

Voided urine was collected for the measurement of protein by dipstick. Proteinuria of $>1+(300 \mathrm{mg}$ per liter in a 24 hour urine collection) was confirmed by testing a clean-catch, midstream sample.

Pre-eclampsia is hypertension associated with proteinuria, after 20 weeks of gestation, in previously normotensive and non proteinuric women. Based on these criteria the women studied were categorized as those who developed preeclampsia or those who remained normotensive.

Urinary calcium to creatinine ratio was calculated and those with ratio less than or equal to 0.04 were considered test positive and those with ratio of $>0.04$ were considered test negative.

The predictive values of urinary calcium to creatinine ratio at less than or equal to 0.04 , for pre-eclampsia, was determined by statistical analysis in control group and the use of supplemental calcium to prevent preeclampsia, was determined by statistical analysis in both the groups.

\section{RESULTS}

In this table, all 100 patients are included, both cases\& control, patients with and without calcium supplementation respectively. In patients with test (CCR) results positive, 9 developed preeclampsia and only 7 were normotensive. While in patient with test (CCR) results negative, only 5 developed preeclampsia \& 79 were normotensive. 
Table 1: Test results in all patients (including cases and control).

\begin{tabular}{|c|c|c|c|}
\hline $\begin{array}{l}\text { Urinary } \\
\text { calcium to } \\
\text { creatinine } \\
\text { ratio (test) }\end{array}$ & Preeclampsia & Normotensive & Total \\
\hline $\begin{array}{l}\text { Positive } \\
\text { (ccr } \\
<=0.04)\end{array}$ & 9 & 7 & 16 \\
\hline $\begin{array}{l}\text { Negative } \\
(\mathrm{ccr}>0.04)\end{array}$ & 5 & 79 & 84 \\
\hline Total & 14 & 86 & 100 \\
\hline
\end{tabular}

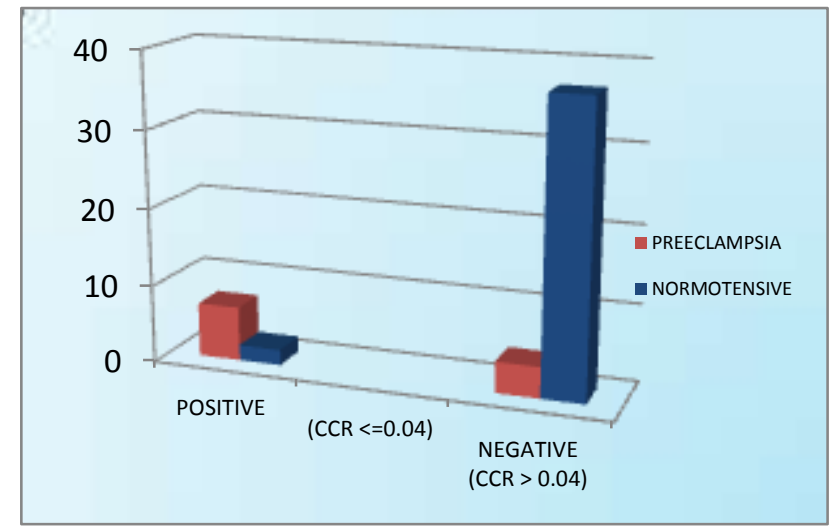

Figure 1: Test results in all patients, (including cases and control).
Table 2: Test results in patients with preeclampsia and normotensive in control (without calcium supplementation).

\begin{tabular}{|llll|}
\hline $\begin{array}{l}\text { Urinary } \\
\text { calcium to } \\
\text { creatinine } \\
\text { ratio(test) }\end{array}$ & Preeclampsia & Normotensive & Total \\
$\begin{array}{l}\text { Positive (ccr } \\
<=0.04)\end{array}$ & 7 & 2 & 9 \\
\hline $\begin{array}{l}\text { Negative (ccr } \\
>0.04)\end{array}$ & 4 & 37 & 41 \\
\hline
\end{tabular}

By Fisher exact test, $\mathrm{p}$ value $<0.01$, which is statistically significant, hence this test (urinary calcium to creatinine ratio) is useful in predicting preeclampsia.

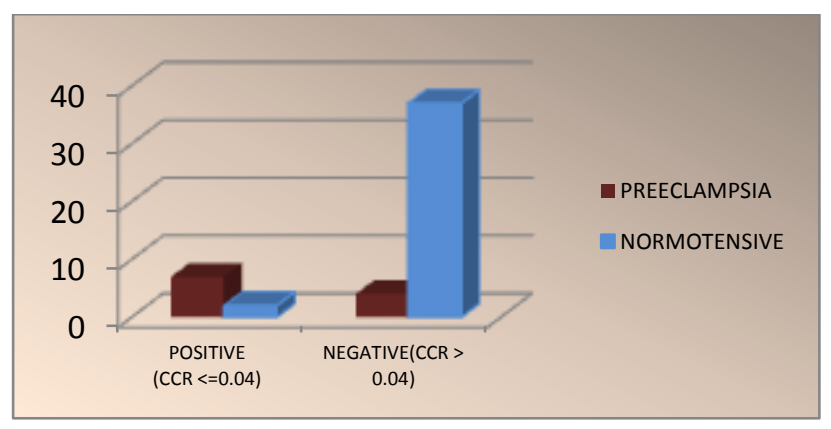

Figure 2: Test results in patients with preeclampsia and normotensive in control (without calcium supplementation).

Table 3: Sensitivity, specificity, PPV and NPV of test in control.

\begin{tabular}{|c|c|c|c|c|}
\hline $\begin{array}{l}\text { Urinary calcium to } \\
\text { creatinine ratio }\end{array}$ & Sensitivity & Specificity & Positive predictive value & $\begin{array}{l}\text { Negative predictive } \\
\text { value }\end{array}$ \\
\hline Test & $63.63 \%$ & $94.87 \%$ & $77.77 \%$ & $90.2 \%$ \\
\hline
\end{tabular}

Table 4: test results in patients with preeclampsia \& normotensive in cases (with calcium supplementation).

\begin{tabular}{|c|c|c|c|}
\hline \multirow{2}{*}{$\begin{array}{l}\text { Urinary } \\
\text { calcium to } \\
\text { creatinine ratio } \\
\text { (test) }\end{array}$} & \multicolumn{2}{|l|}{ Case } & \multirow[b]{2}{*}{ Tota } \\
\hline & Preeclampsia & Normotensive & \\
\hline $\begin{array}{l}\text { Positive (ccr } \\
<=0.04)\end{array}$ & 2 & 5 & 7 \\
\hline $\begin{array}{l}\text { Negative (ccr } \\
>0.04)\end{array}$ & 1 & 42 & 43 \\
\hline
\end{tabular}

By Fisher Exact test, $\mathrm{p}$ value $=0.048$, which is still statistically significant.
These values are seen because this group has received calcium supplementation, which has shown to decrease the incidence of preeclampsia, according to many studies.

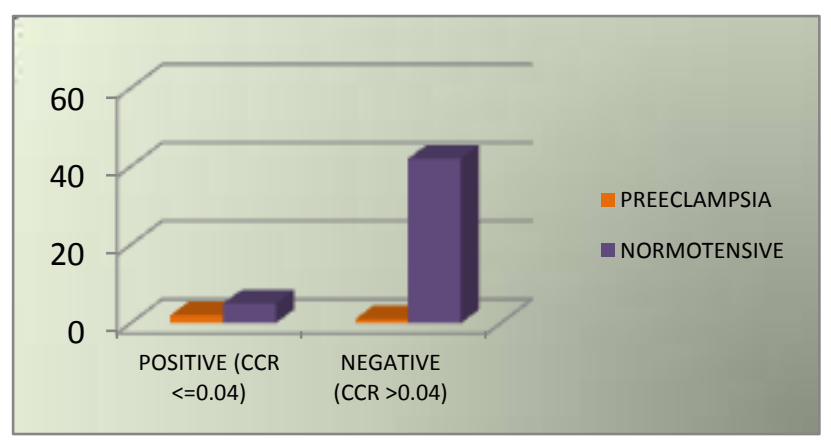

Figure 3: Test results in patients with preeclampsia and normotensive in cases (with calcium supplementation). 
Table 5: Preeclampsia and normotensive patients with and without calcium supplementation.

\begin{tabular}{|llll|}
\hline Patients & \multicolumn{2}{l}{ Calcium supplementation } & Total \\
\cline { 2 - 3 } & Case & Control & \\
\hline Preeclampsia & 3 & 11 & 14 \\
\hline Normal & 47 & 39 & 86 \\
\hline Total & 50 & 50 & 100 \\
\hline
\end{tabular}

By Chi-square test, $\mathrm{p}$ value $=0.02$ which is statically significant.

\section{By Fisher's exact test,p value $=0.041$}

These tables showed that the preeclampsia is less likely to develop in cases compared to controls, as that group has received calcium supplementation.

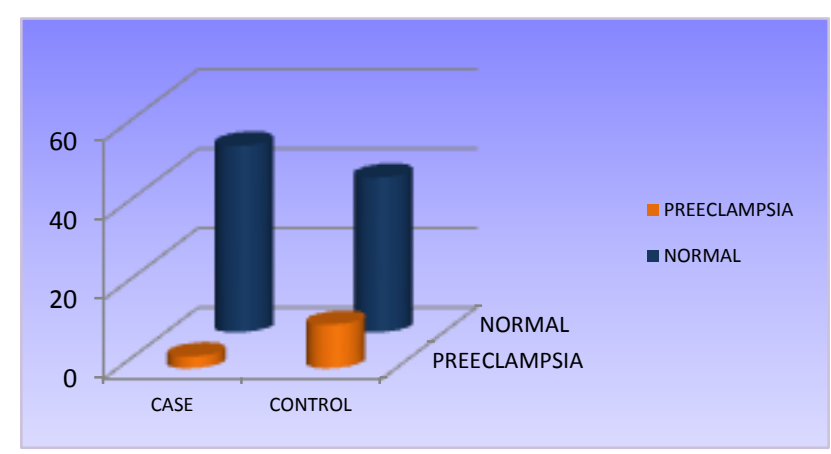

Figure 4: Graph showing preeclampsia and normotensive patients with and without calcium supplementation.

\section{DISCUSSION}

Pre-eclampsia is a complex multisystem disorder. It causes changes in all organ systems, most notably the renal system. Some of these changes in renal function are present in other wise symptom-free patients in whom preeclampsia will eventually develop.

The involvement of the renal system in preeclampsia is in the form of endotheliosis and there is alteration in renal functions. It is found that urinary calcium excretion can be markedly decreased early in the course of preeclampsia, even before the clinical appearance of signs and symptom. This is the basis for using urinary calcium to creatinine ratio as a predictor of preeclampsia. ${ }^{16}$

The challenge of any screening test for preeclampsia is to differentiate between those who are and will remain normotensive versus those who appear normal but will develop preeclampsia.

The use of urinary calcium to creatinine ratio as early predictor of preeclampsia has been studied by various authors.

The present study was done on 100 normotensive patients between 20-38 weeks of gestation or upto delivery and were divided into cases and control depending on calcium supplementation given or not respectively. Urinary calcium to creatinine ratio was calculated from single spot urine sample at 20-24 weeks of gestation and then follow up of cases was done for signs of development of preeclampsia. This test showed a sensitivity of $63.63 \%$, specificity of $94.87 \%$, positive predictive value of $77.77 \%$, negative predictive value of $90.2 \%$.

Thus, the present study confirms that there is a definite relationship between low urinary calcium to creatinine ratio and development of preeclampsia.

Table 6: Comparison of predictive value of calcium creatinine ratio in present study with other studies.

\begin{tabular}{|llllllll|}
\hline Author & Year & No. of patients & Parity & Sensitivity \% & Specificity \% & PPV \% & NPV \% \\
\hline Rodriguezet al $^{8}$ & 1988 & 88 & $>0$ & 70 & 95 & 64 & 96 \\
\hline Sanchez- Ramos et al $^{11}$ & 1991 & 99 & 0 & 88 & 84 & 32 & 99 \\
\hline Ozcan et al $^{14}$ & 1995 & 56 & 0 & 63 & 96 & 71 & 93 \\
\hline RituKamra et al $^{15}$ & 1997 & 104 & $>0$ & 71.4 & 95.5 & 71.4 & 95.5 \\
\hline J Kar et all $^{17}$ & 1999 & 100 & $>0$ & 75 & 94.38 & 64.23 & 96.51 \\
\hline Our study & $2013-14$ & 100 & $>0$ & 63.63 & 94.87 & 77.77 & 90.2 \\
\hline
\end{tabular}

In the study of Rodriguez et $\mathrm{al}^{8}$ (1988), $83 \%$ patients with low CCR developed preeclampsia. In study of Kamra et al (1997) $71.4 \%$ with low CCR developed preeclampsia. In the study of J Kar (1999), 64.2\% with low CCR developed preeclampsia.

The table shows five studies that have investigated the predictive value of low CCR in preeclampsia.
In all the above studies it was found that patients who subsequently developed pre eclamspsia had low urinary calcium excretion. Majority of the patient developed preeclampsia were found to have calcium creatinine ratio of less than 0.04 . 


\section{Calcium supplementation}

Preeclampsia is likely to be a multifactorial disease. However inadequate calcium intake represents a factor associated with an increased incidence of hypertensive disease.

Low calcium intake has been hypothesized to cause increase in blood pressure by stimulating the release of parathyroid hormone and/or renin which leads to increased intracellular calcium concentration in vascular smooth muscle cells and causes vasoconstriction.
Role of calcium supplementation in reducing hypertensive disorders in pregnancy can possibly be explained by reduction in parathyroid calcium release and intracellular calcium concentration, thereby reducing smooth muscle contractility and promoting vasodilatation. Calcium supplementation could also prevent preterm labor and delivery by reducing uterine smooth muscle contractility directly and indirectly by increasing magnesium levels.

Table 7: Characteristics of other trials.

\begin{tabular}{|c|c|c|c|c|}
\hline Study ID & Methods & Participants & Interventions & Conclusion \\
\hline $\begin{array}{l}\text { Belizan et } \\
\text { al. } 1991^{10}\end{array}$ & $\begin{array}{l}\text { Multicentre, } \\
\text { randomized } \\
\text { trial.. Of } 593 \\
\text { women (calcium) } \\
\text { vs } 601 \text { women } \\
\text { (placebo) }\end{array}$ & $\begin{array}{l}\text { Nulliparous women, }<20 \\
\text { weeks pregnant; blood } \\
\text { pressure }<140 / 90 \mathrm{mmHg} \text {; } \\
\text { no present or past disease. }\end{array}$ & $\begin{array}{l}2 \text { g calcium vs identical } \\
\text { looking placebo tablets. } \\
\text { Compliance was } 84 \% \\
\text { (calcium) and } 86 \% \\
\text { (placebo) }\end{array}$ & $\begin{array}{l}\text { Pregnant women who } \\
\text { receive calcium } \\
\text { supplementation after } \\
\text { the } 20 \text { th week of } \\
\text { pregnancy have a } \\
\text { reduced risk of } \\
\text { hypertensive disorders } \\
\text { of pregnancy. }\end{array}$ \\
\hline $\begin{array}{l}\text { Sanchez- } \\
\text { Ramos et al. } \\
1994^{12}\end{array}$ & $\begin{array}{l}\text { Double-blind } \\
\text { placebo- } \\
\text { controlled trial. }\end{array}$ & $\begin{array}{l}\text { Normotensive nulliparas; } \\
\text { positive roll-over test } \\
(281 / 1065) \text { and positive } \\
\text { angiotensin II infusion test at } \\
20-24 \text { weeks of gestation } \\
(67 / 281)\end{array}$ & $\begin{array}{l}\text { Calcium } \\
\text { supplementation with } 2 \\
\text { g/day elemental calcium } \\
\text { vs identical placebo } \\
\text { tablets }\end{array}$ & $\begin{array}{l}\text { Calcium } \\
\text { supplementation given } \\
\text { in pregnancy to high- } \\
\text { risk nulliparas reduces } \\
\text { the incidence of } \\
\text { pregnancy-induced } \\
\text { hypertension. }\end{array}$ \\
\hline $\begin{array}{l}\text { Purwar et } \\
\text { al. } 1996^{13}\end{array}$ & $\begin{array}{l}\text { Double-blind } \\
\text { placebo- } \\
\text { controlled trial. }\end{array}$ & $\begin{array}{l}\text { Nulliparous women; normal } \\
\text { single viable } \\
\text { pregnancy;antenatal clinic } \\
\text { before } 20 \text { weeks; normal } \\
\text { glucose tolerance test; no } \\
\text { hypertension; nounderlying } \\
\text { medical disorders. }\end{array}$ & $\begin{array}{l}\text { Oral calcium containing } \\
2 \text { g elemental calcium } \\
\text { daily, compared with } \\
\text { identical placebo } \\
\text { tablets, taken from } 20 \\
\text { weeks }\end{array}$ & $\begin{array}{l}\text { Calcium } \\
\text { supplementation given } \\
\text { in pregnancy to } \\
\text { nulliparous women } \\
\text { reduces the incidence of } \\
\text { pregnancy induced } \\
\text { hypertension. }\end{array}$ \\
\hline WHO $2006^{9}$ & $\begin{array}{l}\text { Double-blind } \\
\text { placebo- } \\
\text { controlled trial. }\end{array}$ & $\begin{array}{l}\text { Populations with median } \\
\text { daily calcium intake less than } \\
600 \mathrm{mg} \text {; primiparous women } \\
\text { less than } 20 \text { weeks pregnant. } \\
\text { Exclusion criteria: renal } \\
\text { disease or urolithiasis; } \\
\text { parathyroid disease; blood } \\
\text { pressure }>140 \mathrm{mmHg} \\
\text { systolicor }>90 \mathrm{mmHg} \\
\text { diastolic }\end{array}$ & $\begin{array}{l}500 \mathrm{mg} \text { elemental } \\
\text { calcium, three daily, or } \\
\text { identical placebo tablets } \\
\text { from enrolment till } \\
\text { delivery }\end{array}$ & $\begin{array}{l}\text { Calcium } \\
\text { supplementation was } \\
\text { associated with a non- } \\
\text { statistically significant } \\
\text { small reduction in } \\
\text { preeclampsia ( } 4.1 \% \text { vs } \\
4.5 \% \text { ) that was evident } \\
\text { by } 35 \text { weeks of } \\
\text { gestation (1.2\% vs } \\
2.8 \% \text {; }=.04) \text {. } \\
\text { Eclampsia (risk ratio, } \\
0.68: 95 \% \text { CI, } 0.48-0 .\end{array}$ \\
\hline
\end{tabular}

The second explanation could be prevalent malnutrition in developing countries. It had been proposed that hormones involved in blood pressure control are altered during malnutrition and can lead to significant morbidity in malnourished pregnant women.
Calcium supplementation appears to reduce the risk of pre-eclampsia and to reduce the rare occurrence of the composite outcome 'maternal death or serious morbidity'. There were no other clear benefits or harms. (Hofmeyr, G., Duley, L. and Atallah, A. (2007), Dietary calcium supplementation for prevention of pre-eclampsia 
and related problems: a systematic review and commentary. BJOG: An International journal of Obstetrics and Gynaecology.)

In this study, it was seen that out of 50 cases (i.e. with calcium supplementation 2 gm daily) only 3 developed preeclampsia and 47 were normotensive. Out of 50 control (i.e. without calcium supplementation) 11 developed preeclampsia and 39 were normotensive.

The difference between development of preeclampsia is statistically significant $(\mathrm{p}$ value $=0.002)$ between cases and control. Hence preeclampsia is less likely to develop in cases as compared to control as that group had received calcium supplementation. Thus calcium supplementation prevents preeclampsia.

\section{CONCLUSIONS}

The triad of haemorrhage, hypertensive disorders and puerperal sepsis accounted for almost $53 \%$ of the maternal deaths, as stated in a study conducted by Indian Institute of health and family welfare. Our study is an attempt to predict and prevent one of significant cause of maternal mortality, preeclampsia.

This study suggests that an evaluation of urinary calcium to creatinine ratio after $20 \mathrm{wks}$ of gestation may be an effective screening method for impending pre-eclampsia and may identify population at risk, hence can be included in primary prevention programmes. And also this study suggests that simple intervention like calcium supplementation ( 2 gms/day) can help in prevention of preeclampsia in high risk population. Hence this study is an attempt to predict and prevent preeclampsia and reduce maternal mortality.

Funding: No funding sources Conflict of interest: None declared

Ethical approval: The study was approved by the Institutional Ethics Committee

\section{REFERENCES}

1. Zimmer C. Silent struggle: A new theory of pregnancy. The New York Times. 2006:1-4.

2. WHO, 2004. Bethesda, MD. Global Burden of Disease for the Year 2001 by World Bank Region, for Use in Disease Control Priorities in Developing Countries, National Institutes of Health: WHO. Make every mother and child count. World Health Report, 2005, 2nd ed. Geneva:World Health Organization, 2005.

3. Villar J, Betran AP, Gulmezoglu M. Epidemiological basis for the planning of maternal health services. WHO/RHR. 2001.
4. Khedun SM, Moodley J, Naicker T, Maharaj B. Drug management of hypertensive disorders of pregnancy. Pharmacol Ther. 1997;74(2):221-58.

5. Belizan JM, Villar J. The relationship between calcium intake and edema, proteinuria, and hypertension-gestosis: an hypothesis. Am J Clin Nutr. 1980;33:2202-10.

6. Hamlin RHJ. Prevention of pre-eclampsia. Lancet. 1962;1:864-5.

7. ACOG Committee on Obstetric Practice. ACOG practice bulletin. Diagnosis and management of preeclampsia and eclampsia. No. 33, January 2002. American College of Obstetricians and Gynecologists. Obstet Gynecol. 2002;99:159-67.

8. Rodriquez-Thompson D, Lieberman ES. Use of a random urinary protein-to-creatinine ratio for the diagnosis of significant proteinuria during pregnancy. Am J Obstet Gynecol. 2001;185:808-11.

9. Kumar A, Gyaneshwori Devi S, Batra S, Singh C, Shukla DK. Calcium supplementation for the prevention of pre-eclampsia International Journal of Gynecology and Obstetrics. 2009;104:32-6.

10. Curnow KM, Pham T, August P. The L10F mutation of Angiotensinogen is rare in pre-eclampsia. J Hypertension. 2000;18(2):173-8.

11. Sanchez-Ramas L, Jones DC, Cullen MT. Urinary calcium as an early marker for preeclampsia. Obstet Gynecol. 1991;77:685.

12. Villar MA, Sibai BM. Clinical significance of elevated mean arterial pressure in II trimester and threshold increase in blood pressure in systolic or diastolic blood pressure during III trimester. Am J Obstet Gynecol. 1989;160(2):419-23.

13. Leon C, Chesley, Baha M, Sibai. Clinical significance of elevated mean arterial pressure in the second trimester. Am J Obstet Gynecol. 1988;159:275-9.

14. Ozcan T, Kaleli B, Ozeren M, Turan C, Zorlu G, Dr. Zekai Tahir Burak Maternity Hospital, Ankara, Turkey. Urinary calcium to creatinine ratio for predicting preeclampsia. Am J Perinatol. 1995;12(5):349-51.

15. Kamra R, Gupta HP, Das K, Natu SM. J Obstet Gyn Ind. 1997; 47:353.

16. Tolaymat A, Sanchez-Ramos L, Yergey AL, Vieira NE, Abrams SA, Edelstein P. Pathophysiology of hypocalciuria in preeclampsia: measurement of intestinal calcium absorption. Obstet Gynecol. 1994;83(2):239-43.

17. Kar J, Srivastava K, Mishra RK. Role of urinary calcium creatinine ratio in prediction of pregnancy induced hypertension. J Obstet Gynaecol India. 2002;52:39-42.

Cite this article as: Munge AM, Satia MN. Urinary calcium to creatinine ratio to predict preeclampsia and use of calcium supplementation to prevent preeclampsia. Int J Reprod Contracept Obstet Gynecol 2016:5:1380-5. 